\title{
Analisis Ergonomika Penggunaan Mini Rice Combine Harvester
}

\author{
Ergonomics Analysis of Rice Combine Harvester \\ Rahmat Suyisto ${ }^{1}$, Bambang Purwantana ${ }^{1}$, Guntarti Tatik Mulyati ${ }^{*}$ \\ ${ }^{1}$ Departemen Teknik Pertanian dan Biosistem, Fakultas Teknologi Pertanian, Universitas Gadjah Mada, Jl. Flora No 1, \\ Bulaksumur, Yogyakarta 55281, Indonesia \\ ${ }^{2}$ Departemen Teknologi Industri Pertanian, Fakultas Teknologi Pertanian, Universitas Gadjah Mada, \\ Jl. Flora No 1, Bulaksumur, Yogyakarta 55281, Indonesia \\ *Penulis korespondensi: Guntarti Tatik Mulyati, Email: guntarti.ftp@ugm.ac.id
}

Tanggal submisi: 12 Agustus 2018; Tanggal revisi: 2 Mei 2020; 1 Maret 2021; Tanggal penerimaan: 12 Maret 2021

\begin{abstract}
ABSTRAK
Mini rice combine harvester adalah mesin pemanen padi yang saat ini banyak dioperasikan di lahan sawah. Penelitian ini bertujuan untuk mengetahui ergonomika mesin mini rice combine harvester dalam pemanenan padi di lahan sawah berukuran sempit. Pengujian ergonomika dilakukan berdasarkan karakteristik mekanis mesin dan karakteristik fisiologi operator. Karakteristik mesin diukur dari getaran mesin, polusi suara serta polusi debu yang dihasilkan. Karakteristik fisiologi operator diukur dari beban kerja yang digambarkan dengan perubahan denyut jantung kerja, suhu tubuh, kesakitan pada anggota tubuh yang dirasakan operator. Hasil penelitian menunjukkan bahwa harvester yang diuji mempunyai getaran mesin sebesar 14,2 m/dt², kebisingan 92,4 dB, melebihi ambang batas kesehatan yaitu sebesar $6 \mathrm{~m} / \mathrm{dt}^{2}$ dan $80 \mathrm{~dB}$. Disarankan operasional mesin dilakukan secara bergantian operator dengan periode untuk setiap operator tidak lebih dari 1 jam. Debu yang dihasilkan menurut ISO 14644-1 termasuk kelas 6 atau bersih dan tidak membahayakan operator. Beban kerja berdasarkan pengukuran denyut jantung operator adalah sangat ringan - sedang. Hasil analisis kesakitan akibat kerja menunjukkan $14 \%$ anggota tubuh terasa sedikit sakit dan 3,3\% anggota tubuh sangat sakit. Secara umum disimpulkan bahwa untuk dapat memenuhi kelayakan dari aspek ergonomi perlu dilakukan upaya perbaikan disain untuk menurunkan getaran dan kebisingan mesin.
\end{abstract}

Kata kunci: Ergonomi; mini-combine; operator; panen; padi

\begin{abstract}
Mini rice combined harvester is currently being operated in paddy fields. This study aims to determine the ergonomics of mini rice combine harvester machine in harvesting rice on narrow paddy fields. Ergonomics analysis was carried out based on the mechanical characteristics of the machine and the physiological characteristics of the operator. Besides, the engine characteristics were measured from engine vibration, as well as noise and dust pollution produced while the operators' physiological characteristics were measured from the workload illustrated
\end{abstract}


by changes in heart rate, body temperature, and pain felt in the limbs. The results showed that the harvester had an engine vibration of $14.2 \mathrm{~m} / \mathrm{sec}^{2}$, noise $92.4 \mathrm{~dB}$, exceeding the health threshold of $6 \mathrm{~m} / \mathrm{sec}^{2} \mathrm{and} 80 \mathrm{~dB}$. It is recommended that operation be carried out alternately with the operator period not more than 1 hour. The dust generated according to ISO 14644-1 was class 6 or clean and does not endanger the operator. Moreover, workloads based on operator heart rate measurements were very mild - moderate. The work-related pain analysis showed that $14 \%$ of the limbs felt a little sick while $3.3 \%$ were very ill. In general, it was concluded that to meet feasibility in relation to ergonomic aspects, there is need for design improvement efforts to reduce engine vibration and noise.

Keywords: Ergonomics; harvest; mini-combine; operator harvest; rice

\section{PENDAHULUAN}

Beras merupakan makanan pokok penduduk Indonesia sehingga sebagian besar lahan pertanian di Indonesia ditanami padi. Sebagai salah satu upaya untuk membantu proses produksi budidaya padi, khususnya dalam pekerjaan panen, Kementerian Pertanian RI mengintroduksikan bantuan teknologi dalam bentuk mesin pemanen padi rice combine harvester di banyak daerah di Indonesia (Sulaiman, 2018). Untuk wilayah pulau Jawa mesin pemanen yang dikenalkan pada umumnya berupa mesin panen mini, mini rice combine harvester. Hal ini mengingat rata-rata kepemilikan lahan di Jawa kurang dari $2.000 \mathrm{~m}^{2} /$ keluarga petani (BPS, 2013).

Penggunaan mesin panen ditujukan untuk meningkatkan produktivitas panen padi sawah. Sebagai bentuk teknologi yang melibatkan mesin dan manusia, kinerja mesin panen padi sangat ditentukan seberapa optimal interaksi keduanya. Interaksi optimal antara manusia dan mesin dapat tercapai jika ada integrasi data antropometri dengan disain teknis. Meski mesin rice combine pada umumnya telah dirancang dengan teknologi tinggi, dampak negatif dari penggunaan mesin ini juga masih sering dilaporkan (Mehta dkk., 2008). Salah satu yang sering dilaporkan adalah disain tempat duduk tidak nyaman bagi operator (Ghaderi dkk, 2014; Mehta dkk., 2008), karena ukurannya yang lebih kecil dibanding antropometri operator setempat (Mulyati dkk., 2020). Interaksi optimal antara operator dan mesin dapat dicapai dengan mengintegrasikan data antropometri operator dengan disain teknis mesinnya (Ghaderi dkk., 2014).

Sumer dkk. (2006) melaporkan adanya kebisingan pada mesin pemanen yang disebabkan oleh getaran mesin. Operator merasakan getaran pada seluruh tubuh (whole- body vibration: WBV) saat mengoperasikan mesin, terutama pada kondisi lahan basah yang menyebabkan getaran yang lebih besar yang dirasakan operator mesin (Almosawi dkk., 2016). Jika mesin terasa tidak nyaman bagi operator maka kemungkinan terjadinya kecelakaan menjadi besar. Disamping memperbaiki kenyamanan, disain mesin pemanen yang sesuai juga meningkatkan efisiensi penggunaan energinya. Peningkatan disain mesin dilaporkan dapat mengurangi kebutuhan energi sebesar 13-29\% (Mehta dkk., 2008).

Paparan whole-body vibration di akhir waktu kerja secara signifikan berhubungan dengan cedera pada otot, rangka dan syaraf (musculoskeletal disorders: MSDs) di bagian leher, bahu dan lengan (Charles dkk., 2017). Kebisingan adalah faktor lain yang mengganggu operator, menyebabkan operator menjadi kurang hati-hati, lelah, mempengaruhi kapasitas kerja dan menurunkan batas keselamatan kerja (Sumer dkk, 2006). Dua hal inilah yang mendorong dilakukannya penelitian mengenai ergonomika mesin mini rice combine harvester yang banyak dipakai di provinsi Daerah Istimewa Yogykarta. Tujuan penellitian ini adalah mengetahui ergonomika mesin mini rice combine harvester berdasarkan karakteristik mekanis mesin dan karakteristik fisiologi operatornya. Hasil penelitian diharapkan dapat digunakan sebagai bahan rekomendasi operasional dan perbaikan disain mesin.

\section{METODE PENELITIAN}

\section{Operator dan Mesin}

Operator pertama adalah operator senior mesin combine, dengan Indeks Masa Tubuh IMT=28,41. Indeks masa tubuh adalah salah satu tolok ukur berat ideal masyarakat Indonesia, dengan IMT normal adalah 18,5-25. Pengalaman lebih dari 2 tahun sebagai operator mesin combine. Operator kedua adalah operator yunior dengan pengalaman kurang dari 2 tahun sebagai operator mesin combine, dengan IMT=34,06. Kedua operator mempunyai IMT termasuk dalam kelas kelebihan berat badan tingkat berat.

Mesin pemanen adalah bantuan pemerintah untuk petani Kecamatan Seyegan, Sleman, Yogyakarta. Spesifikasi mesin adalah Quick combine harvester tipe $\mathrm{H}-140 \mathrm{R}$ dengan mesin Kubota 4 tak, maximum power 14 HP, 2.400 rpm, kapasitas panen 6-7 jam/hektar. 


\section{Karakteristik Mekanis}

Karakteristik mekanis seperti getaran mesin diukur menggunakan alat vibration meter, polusi suara atau kebisingan dengan sound levelmeter, dan polusi debu menggunakan Trotec. Pengukuran dilakukan saat mesin digunakan untuk melakukan pemanenan padi sawah.

\section{Getaran}

Pengukuran getaran pada tubuh operator dihitung berdasarkan Peraturan Menteri Kesehatan nomor 70 tahun 2016 seperti ditunjukkan pada Persamaan 1 dan 2. Bagian yang diukur getarannya adalah besi tempat duduk, lantai mesin tempat peletakan kaki dan bagian kemudi rice combine harvester. Pegukuran pada bagianbagian tersebut diukur pada masing-masing sumbu $x, y$, dan $z$. Hasil dari pengukuran getaran yang terbaca oleh Vibration Meter selanjutnya dimasukkan ke perhitungan resultan untuk pajanan getaran seluruh tubuh untuk resultan 3 aksis $(x, y$, dan $z)$ dengan crest factor (nilai perbandingan akselerasi tertinggi dengan akselerasi terendah) yakni $>6$ hingga 9. Persamaan berdasarkan Peraturan Menteri Kesehatan Nomor 70 tahun 2016, adalah:

$a_{w l}(8)=\left(\frac{1}{T_{0}} \sum a_{w l j}^{2} \cdot T_{j}\right)^{\frac{1}{2}}$

Di mana $a_{w l}(8)=$ pajanan harian getaran selama 8 jam untuk aksis $x, y$, dan $z\left(\mathrm{~ms}^{-2} \mathrm{rms}\right) ; a_{w / j}=$ nilai total pembebanan akselerasi pada aksis $x, y$, atau $z$ selama periode pajanan $j\left(\mathrm{~ms}^{-2} \mathrm{rms}\right)$. Untuk nilai pembebanan dapat dilihat pada Tabel $1 ;$ dan $T_{j}=$ durasi selama periode pajanan $\mathrm{j}$ (detik).

$$
A_{w x}=\sqrt{\sum\left(W_{f x} A_{f x}\right)^{2}}
$$

Di mana $A_{w x}=$ total nilai akselerasi yang terukur dengan faktor pembebanan (weighted rms acceleration) untuk aksis $x ; W_{f}=$ faktor pembebanan untuk aksis $\mathrm{x}$ pada setiap 1/3 frekuensi octave band dari 1 hingga 80 Hertz; dan $A_{f}=$ nilai akselerasi rms untuk spektrum aksis $x$ pada setiap $1 / 3$ frekuensi octave band dari 1 hingga 80 Hertz.

Nilai faktor pembebanan pada masing-masing aksis dapat dilihat pada Tabel 1.

Nilai hasil perhitungan resultan pajanan getaran seluruh tubuh dengan crest factor 6-9 untuk durasi pajanan tertentu dapat dilihat pada Tabel 2.

Menurut SNI 8185:2015 mesin panen padi kombinasi - syarat mutu dan metode uji, ambang batas getaran pada mesin combine harvester adalah $6 \mathrm{~m} / \mathrm{dt}^{2}$ (Anonim, 2015).

Tabel 1. Faktor pembebanan untuk menghitung resultan getaran seluruh tubuh

\begin{tabular}{ccc}
\hline \multirow{2}{*}{ Frekuensi (Herz) } & \multicolumn{2}{c}{ Faktor pembebanan } \\
\cline { 2 - 3 } & $\begin{array}{c}\text { Vibrasi } \\
\text { longitudinal } z\end{array}$ & $\begin{array}{c}\text { Vibrasi } \\
\text { transversal } x, y\end{array}$ \\
\hline 1 & 0,5 & 1 \\
1,25 &, 56 & 1 \\
1,6 & 0,63 & 1 \\
2 & 0,71 & 1 \\
2,5 & 0,8 & 0,8 \\
3,15 & 0,9 & 0,63 \\
4 & 1 & 0,5 \\
5 & 1 & 0,4 \\
6,3 & 1 & 0,315 \\
8 & 1 & 0,25 \\
10 & 0,8 & 0,2 \\
12,5 & 0,63 & 0,16 \\
16 & 0,5 & 0,125 \\
20 & 0,4 & 0,1 \\
25 & 0,315 & 0,08 \\
31,5 & 0,25 & 0,063 \\
40 & 0,2 & 0,05 \\
50 & 0,16 & 0,04 \\
63 & 0,125 & 0,0315 \\
80 & 0,1 & 0,025 \\
\hline
\end{tabular}

Sumber: Peraturan Menteri Kesehatan Nomor 70 tahun 2016

Tabel 2. Nilai ambang batas getaran seluruh tubuh untuk resultan 3 aksis ( $x, y$, dan $z$ ) dengan crest factor> 6 hingga 9

\begin{tabular}{cc}
\hline Durasi (jam) & $\begin{array}{c}\text { NAB resultan 3 aksis } \\
(x, y, z)\left(\text { meter/detik }{ }^{2}\right)\end{array}$ \\
\hline 0,1667 & 6,0000 \\
0,5000 & 3,4644 \\
1,0000 & 2,4497 \\
2,0000 & 1,7322 \\
4,0000 & 1,2249 \\
8,0000 & 0,8661 \\
24,0000 & 0,5000 \\
\hline
\end{tabular}

Sumber: Depkes RI, 2016 


\section{Kebisingan}

Pengukuran tingkat kebisingan dilakukan dengan mengunakan alat ukur sound level meter tipe digital, Dua cara pengukuran yaitu pengukuran dengan radius $2 \mathrm{~m}$ untuk kebisingan yang diderita operator dan radius 10 meter dari rice combine harvester untuk kebisingan lingkungan. Hubungan tingkat suara (kebisingan) dengan lama pendengaran yang diizinkan berdasarkan Peraturan Menteri Kesehatan dapat dilihat pada Tabel 3.

\section{Polusi debu}

Pengukuran partikel debu dilakukan dengan mengunakan alat Pengukur Debu Trotec tipe PC220. Pengukuran dilakukan pada radius $2 \mathrm{~m}$ dari exhaust rice combine harvester atau sekitar $30 \mathrm{~cm}$ dari hidung dengan tinggi $150 \mathrm{~cm}$ atau setinggi letak hidung pada manusia normalnya. Pengambilan data dilakukan setiap 10 menit sekali per hari kerja. Hasil dari pengukuran jumlah partikel debu ini diambil rata-ratanya, kemudian di kategorikan sesuai kelas tingkat kebersihannya dengan mengacu pada ISO 14644-1 (Tabel 4).

\section{Karakteristik Fisiologis}

Karakteristik fisiologis operator dilakukan saat operator mengoperasikan mesin yang dibantu seorang helper. Beban kerja ditinjau dari denyut jantung kerja diukur menggunakan Automatic Wrist Blood Pressure Monitor Omron tipe HEM-6121 yang terpasang di pergelangan tangan operator. Pengukuran denyut jantung dilakukan setiap jam selama operator bekerja.
Tabel 3. Nilai ambang batas pemaparan kebisingan perhari kerja berdasarkan intensitas yang diterima pekerja

\begin{tabular}{ccc}
\hline $\begin{array}{c}\text { Batas waktu } \\
\text { pemaparan } \\
\text { per hari kerja }\end{array}$ & Satuan & $\begin{array}{c}\text { Intensitas } \\
\text { kebisingan } \\
(\mathrm{dB})\end{array}$ \\
\hline 8 & jam & 85 \\
4 & jam & 88 \\
2 & jam & 91 \\
1 & jam & 94 \\
30 & menit & 97 \\
15 & menit & 100 \\
7,5 & menit & 103 \\
3,75 & menit & 106 \\
1,88 & menit & 109 \\
0,94 & menit & 112 \\
28,12 & detik & 115 \\
14,06 & detik & 118 \\
7,03 & detik & 121 \\
3,52 & detik & 124 \\
1,76 & detik & 127 \\
0,88 & detik & 130 \\
0,44 & detik & 133 \\
0,22 & Detik & 135 \\
0,11 & Detik & 139 \\
\hline
\end{tabular}

Sumber: Depkes RI, 2016

Tabel 4. Kelas kebersihan partikel di udara

\begin{tabular}{ccccccc}
\hline \multirow{2}{*}{$\begin{array}{c}\text { Klasifikasi } \\
(\mathrm{N})\end{array}$} & \multicolumn{5}{c}{$\begin{array}{c}\text { Batas konsentrasi maksimum } \\
\text { (partikulat/m } \\
\text { lebih besar dari diameter }\end{array}$} \\
\cline { 2 - 7 } & $0,1 \mu \mathrm{m}$ & $0,2 \mu \mathrm{m}$ & $0,3 \mu \mathrm{m}$ & $0,5 \mu \mathrm{m}$ & $1 \mu \mathrm{m}$ & $5 \mu \mathrm{m}$ \\
\hline ISO class 1 & 10 & 2 & & & & \\
ISO class 2 & 100 & 24 & 10 & 4 & 8 & \\
ISO class 3 & 1000 & 237 & 102 & 35 & 83 & \\
ISO class 4 & 10000 & 2370 & 1020 & 352 & 832 & 29 \\
ISO class 5 & 100000 & 23700 & 10200 & 3520 & 35200 & 293 \\
ISO class 6 & 1000000 & 237000 & 102000 & 35200 & 8320 & 2930 \\
ISO class 7 & & & & 352000 & 83200 & 29300 \\
ISO class 8 & & & & 3520000 & 832000 & 293000 \\
ISO class 9 & & & & 35200000 & 8320000 & \\
\hline
\end{tabular}

Sumber: ISO 14644-1 
Standard beban kerja ini mengikuti American Industrial Hygiene Association seperti terdapat pada Tabel 5.

Dengan menggunakan standar pada Tabel American Industrial Hygiene Association Sanders (1987) (dalam Kroemer dkk., 2004) yang sama, konsumsi oksigen dan pengeluaran energi dihitung menggunakan Persamaan 3 dan 4.

Laju konsumsi oksigen:

$Y=1,4259+0,0207 X+0,0202 . B S A$

Di mana: $Y=$ laju konsumsi oksigen (liter/menit); $X=$ denyut nadi (puls/menit); $B S A=0,007184 \times W t^{0,425} \mathrm{Ht}^{0,725}$ (Dubois, 1916); $B S A=$ luas permukaan tubuh $\left(\mathrm{m}^{2}\right) ; W t$ = berat tubuh $(\mathrm{kg})$; dan $\mathrm{Ht}=$ tinggi badan $(\mathrm{cm})$.

Pengeluaran energi mengunakan Persamaan Oki (1994) dalam Herodian (1998) (Persamaan 4).

$P=4,75 * Y$

Di mana: $P=$ energi yang dikeluarkan (kkal/menit); 4,75 $=$ asumsi nilai konversi pada RQ (perbandingan kadar $\mathrm{CO}_{2}$ dan $\mathrm{O}_{2}$ ); dan $Y=$ Laju konsumsi oksigen ( $\mathrm{L} /$ menit).

\section{HASIL DAN PEMBAHASAN}

\section{Getaran}

Getaran berasal dari mesin rice combine harvester yang bertipe mesin 4 tak dan mempunyai tenaga maksimal $14 \mathrm{HP} / 2400 \mathrm{rpm}$. Pengukuran getaran dilakukan pada dua titik bagian rice combine harvester yang terkena langsung oleh operator. Bagian ini adalah besi tempat duduk, sandaran kaki dan bagian kemudi. Pengukuran pada masing-masing sumbu $x, y$, dan $z$. Rerata getaran dapat dilihat pada Tabel 6.
Tabel 6. Rerata getaran rice combine harvester pada sumbu $x, y$, dan $z$

\begin{tabular}{cccc}
\hline \multirow{2}{*}{ Operator } & \multicolumn{3}{c}{ Getaran $\left(\mathrm{m} / \mathrm{dt}^{2}\right)$} \\
\cline { 2 - 4 } & $\mathrm{x}$ & $\mathrm{y}$ & $\mathrm{z}$ \\
\hline I & 9,0 & 8,7 & 14,0 \\
II & 8,9 & 8,6 & 13,8 \\
\hline
\end{tabular}

Getaran mesin yang sedikit berbeda disebabkan oleh kondisi lahan yang berbeda. Dari Tabel 6 dapat dilihat bahwa aksis z yaitu gerakan bolak-balik keatas dan kebawah menghasilkan getaran yang paling besar. Hal ini membuktikan bahwa getaran mesin lebih dominan ke arah vertikal, atas-bawah. Sedangkan aksis $x$ dan aksis y yang bergerak bolak-balik ke kanan dan kiri serta ke depan dan belakang cenderung memiliki nilai yang hampir sama. Jika dibangdingkan dengan SNI, nilai getaran ini tergolong tinggi, karena untuk SNI mesin pemanen padi (rice combine harvester) nilai maksimal getaran adalah $6 \mathrm{~m} / \mathrm{dt}^{2}$.

Perhitungan resultan untuk pajanan getaran seluruh tubuh untuk resultan 3 aksis $(x, y$, dan $z)$ dengan crest factor> 6 hingga 9 dilakukan dengan mencari nilai $a_{w 1}(8)$, yaitu pajanan harian getaran selama 8 jam untuk aksis $\mathrm{x}$, y dan z. Nilai tersebut adalah jumlah dari $A w$ (nilai akselerasi yang terukur dengan faktor pembebanan pada masing masing aksis $x, y$, dan z) terhadap waktu selama 8 jam pajanan harian. Faktor pembebanan untuk menghitung resultan getaran seluruh tubuh pada masing masing aksis $x, y$, dan $z$ dapat dilihat pada Tabel 1 . Selanjutnya, hasil dari nilai $a_{w l}(8)$ di interpolasi dengan durasi nilai ambang batas getaran seluruh tubuh untuk resultan 3 aksis $x, y$, dan $z$ dengan crest factor $>6$ hingga 9 yang dapat dilihat pada Tabel 2. Hasil dari perhitungan tersebut diperoleh nilai $\mathrm{a}_{\mathrm{wl}}(8)\left(\mathrm{m} / d \mathrm{t}^{2}\right)=2,44$. Maka durasi diijinkan untuk

Tabel 5. Kategori beban kerja, konsumsi oksigen, denyut jantung dan pengeluaran energi

\begin{tabular}{lccc}
\hline Beban Kerja & $\begin{array}{c}\text { Konsumsi oksigen (L/ } \\
\text { menit) }\end{array}$ & $\begin{array}{c}\text { Denyut jantung } \\
\text { (denyut/menit) }\end{array}$ & $\begin{array}{c}\text { Pengeluaran energi } \\
\text { (kkal/menit) }\end{array}$ \\
\hline Istirahat & $<0,3$ & $60-70$ & $<1,5$ \\
Sangat ringan & $0,32-0,5$ & $65-75$ & $1,6-2,5$ \\
Ringan & $0,5-1,0$ & $75-100$ & $2,5-5,0$ \\
Sedang & $1,0-1,5$ & $100-125$ & $5,0-7,5$ \\
Berat & $1,5-2,0$ & $125-150$ & $7,5-10,0$ \\
Sangat berat & $2,0-2,5$ & $150-180$ & $10,0-12,5$ \\
Luar biasa berat & $>2,5$ & $>180$ & $>12,5$ \\
\hline
\end{tabular}

Sumber: Kroemer dkk. (2004) 
mengoprerasikan mesin tersebut hanya 1,01 jam dalam 1 hari. Artinya mesin combine ini dinilai tidak aman untuk operator berdasarkan Peraturan Menteri nomor 70 tahun 2016 (Anonim, 2016). Menurut penelitian Mulyati dkk, (2020) mesin tipe ini mempunyai getaran mesin paling besar dibandingkan dengan mesin rice combine harvester JAP001 dan Tanikaya tipe HT12, karena mesin ini menggunakan alat gerak dari "krepyak besi", sedang yang lain menggunakan krepyak karet.

Jika operator terpapar getaran di seluruh tubuh (whole Body Vibration: WBV) maka Musculoskeletal Disorders MSDs) yang dirasakan operator menjadi lima kali lipatnya (Charles dkk., 2017). Paparan risiko MSDs sangat tinggi pada pengemudi taksi (Bulduk dkk., 2014).

\section{Kebisingan}

Pengukuran intensitas kebisingan dilakukan pada jarak $2 \mathrm{~m}$ dan $10 \mathrm{~m}$ dari mesin atau sumber suara. Pengukuran pada jarak $2 \mathrm{~m}$ diasumsikan sebagai intensitas suara yang diterima oleh operator, sedangkan pengukuran pada jarak $10 \mathrm{~m}$ diasumsikan sebagai suara mesin yang mempengaruhi lingkungan sekitar. Sound level meter dipasang pada ketinggian 1,5 $\mathrm{m}$ atau setinggi telinga. Hasil pengukuran kebisingan dan nilai ambang batas untuk lamanya operator terpapar pada kebisingan tersebut ditunjukkan pada Tabel 7.

Tabel 7. Intensitas kebisingan dan lama maksimal operator terpajan kebisingan

\begin{tabular}{cccc}
\hline \multicolumn{2}{c}{ Kebisingan $(\mathrm{dB})$} & \multicolumn{2}{c}{ NAB (Jam) } \\
\hline $2 \mathrm{~m}$ & $10 \mathrm{~m}$ & $2 \mathrm{~m}$ & $10 \mathrm{~m}$ \\
92,4 & 80,5 & 1,5 & $>8$ \\
\hline
\end{tabular}

Dari Tabel 7 dapat disimpulkan bahwa operator mesin combine dikhawatirkan akan terganggu pendengarannya kalau terpapar kebisingan 92,4 dB selama 8 jam sehari, oleh sebab itu sesuai Peraturan Menteri Kesehatan, operator hanya diijinkan maksimal mengoperasikan mesin combine 1,5 jam saja selama 1 hari. Orang-orang di sekitar mesin pada jarak $>10 \mathrm{~m}$, tidak masalah terpapar kebisingan mesin 80,5 dB meski lebih dari 8 jam sehari. Getaran yang tinggi menyebabkan kebisingan mesin meningkat. Dibandingkan dengan mesin rice combine harvester yang lain, mesin ini mempunyai kebisingan paling tinggi, diikuti mesin Tanikaya dan terakhir mesin JAP (Mulyati dkk., 2020).

\section{Partikel Debu}

Hasil pengukuran partikel debu ditunjukkan pada Tabel 8. Standar ISO 14644-1 (Anonim, 2005) mempunyai 9 kategori kelas konsentrasi maksimum kebersihan partikulat udara (partikel $/ \mathrm{m}^{3}$ udara). ISO kelas 1 merupakan kategori kelas terendah dari kontaminasi partikel debu, atau sebagai kelas terbersih untuk suatu hasil pengukuran cemaran partikel debu di udara. Sedangkan ISO kelas 9 merupakan kategori tertinggi dari kontaminasi partikel debu. Pengukuran pada jarak 2 meter diasumsikan sebagai partikel debu yang diterima langsung oleh operator.

Berdasarkan hasil tersebut diketahui bahwa klasifikasi kebersihan udara partikel debu yang dapat terhirup oleh operator dapat dikategorikan kedalam ISO kelas 6, yaitu terkategori fasilitas ruang bersih. Artinya, tingkat kebersihan udara pada jarak 2 meter atau yang diterima langsung oleh operator masih tergolong aman, sehingga lingkungan masih bersih dan manusia bisa beraktivitas seperti biasa di lingkungan tersebut.

Perjalanan debu masuk saluran pernafasan dipengaruhi oleh ukuran partikel. Menurut Departemen Kesehatan RI (1997) bahwa ukuran partikulat debu yang membahayakan kesehatan umumnya berkisar antara 0,1 mikron sampai 10 mikron. Partikel yang berukuran 5 mikron atau lebih akan mengendap di hidung, nasofaring, trakea dan percabangan bronkus. Partikel yang berukuran kurang dari 2 mikron akan berhenti di bronkiolus dan alveolus. Partikel yang berukuran kurang dari 0,5 mikron biasanya tidak sampai mengendap di saluran pernafasan akan tetapi dikeluarkan lagi. Dalam penelitian ini hasil pengukuran debu yang dapat terhirup operator pada ukuran debu 2,5 - $10 \mu \mathrm{m}$ masih tergolong banyak. Hal ini dapat menyebabkan kotoran debu sekam mengendap di hidung, nasofaring, trakea dan percabangan bronkus. Debu ini akan mengganggu kesehatan pernafasan apabila pekerjaan ini dilakukan dalam waktu yang lama dan tanpa alat penutup hidung atau masker. Oleh sebab itu, meskipun masih tergolong aman, pemakaian masker untuk operator mesin pemanen sangat direkomendasikan.

Tabel 8. Rerata partikel debu di sekitar mesin combine

\begin{tabular}{ccccccc}
\hline \multicolumn{5}{c}{ Partikel debu (partikel $/ \mathrm{m}^{3}$ udara) } & Kategori \\
\cline { 1 - 6 } $0,3 \mu \mathrm{m}$ & $0,5 \mu \mathrm{m}$ & $1,0 \mu \mathrm{m}$ & $2,5 \mu \mathrm{m}$ & $5,0 \mu \mathrm{m}$ & $10 \mu \mathrm{m}$ & ISO \\
\hline 47.829 & 18.099 & 4.133 & 720 & 164 & 89 & ISO class 6 \\
\hline
\end{tabular}




\section{Denyut jantung, Suhu Tubuh, dan Faktor Lingkungan}

Menurut Grandjean dalam Nurmianto (2003) meningkatnya denyut nadi disebabkan oleh beberapa faktor yaitu temperatur atau suhu sekeliling yang tinggi, tingginya pembebanan otot statis dan semakin sedikit otot yang terlibat dalam suatu kondisi kerja. Berdasarkan beberapa faktor itulah denyut jantung dapat dipakai sebagai Indeks beban kerja. Gambar 1 menunjukkan hubungan antara waktu dengan perubahan denyut jantung.

Ditinjau dari pola denyut jantung kedua kategori operator, kenaikan denyut jantung terjadi mengikuti pola yang sama, dengan denyut tertinggi pada sekitar pukul 11-12 siang. Pada denyut tertinggi ini diduga kelelahan sudah terjadi pada kedua operator sehingga untuk waktu kerja selanjutnya tubuh akan menurunkan ritme kerjanya yang mengakibatkan denyut jantung semakin menurun. Setelah berhenti bekerja, tubuh akan melakukan recovery sehingga denyut jantungnya akan menurun menjadi seperti sediakala.

Pada saat denyut jantung mencapai puncaknya, suhu tubuh juga mencapai puncak tertinggi. Operator yang lebih tua usianya mencapai puncak denyut jantung pada sekitar pukul 11-12 yang lebih cepat dibanding dengan operator yang lebih muda. Perubahan suhu tubuh operator ini lebih landai dengan suhu tertinggi $36,5{ }^{\circ} \mathrm{C}$ (Gambar 2). Sedangkan operator dengan usia muda, denyut jantung mencapai puncaknya lebih lambat, disertai dengan memuncaknya suhu tubuh yang hampir $38^{\circ} \mathrm{C}$, yang terjadi saat suhu lingkungan juga mencapai puncaknya.

Menurut Yassierli dan Iridiastadi (2014) fisiologi kerja seorang operator terlihat dari perubahan denyut jantungnya. Denyut jantung tertinggi pada pukul 11 siang. Ini adalah waktu untuk istirahat operator. Denyut jantung ini sangat dipengaruhi oleh stres operator dan kondisi lingkungan.

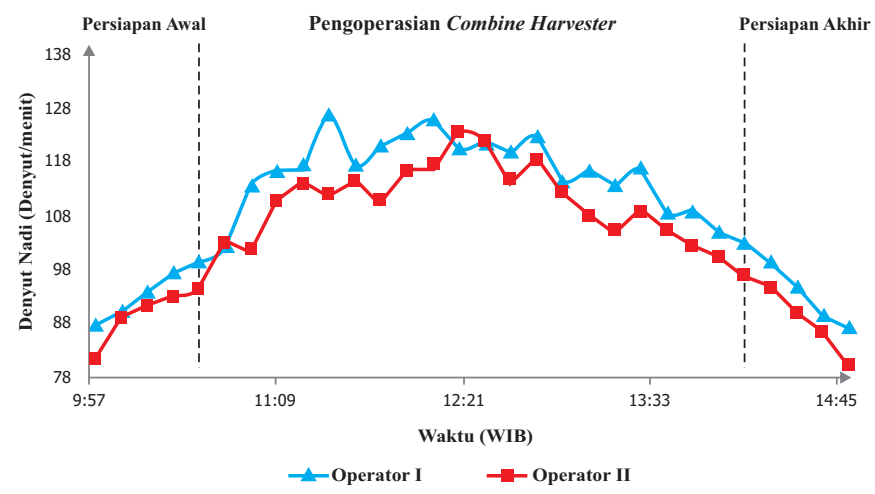

Gambar 1. Denyut Jantung
Pada pengamatan ini suhu lingkungan berkisar 30-37 ${ }^{\circ} \mathrm{C}$ dengan kelembapan rata-rata $59,25 \%$. Suhu tinggi dan kelembapan relatif tinggi ini berdampak negatif ke operator karena suhu tubuh operator naik dan berkeringat, sementara keringat tidak dapat cepat mengering karena kelembaban udara sekitarnya tinggi. Ini berakibat baju operator akan tetap basah yang dapat mengakibatkan penurunan stamina. Kondisi ini dapat diminimalisir dampaknya dengan cara berganti pakaian saat pakaian yang dikenakan sudah basah terkena keringat.

Dengan menggunakan persamaan 3 dan 4 dapat dihitung konsumsi oksigen dan pengeluaran energi seperti ditunjukkan hasilnya pada Tabel 9. Hasil perhitungan terbagi menjadi 3 seperti yang tertera pada gambar denyut jantung dan suhu tubuh, yaitu kegiatan persiapan awal, pengoperasian, dan persiapan akhir saat akan selesai.

Dari konsumsi oksigen, pola denyut jantung dan pengeluaran energi operator dapat disimpulkan bahwa rata-rata beban kerja yang dirasakan operator I berada pada level beban kerja ringan-sedang, operator II berada pada level sangat ringan-ringan sesuai pengkelasan pada Tabel 5. Beban kerja fisik seseorang berhubungan dengan denyut jantung dan kebutuhan energi untuk bekerja (Guastello, 2014).

Dibandingkan dengan pekerja panen metode panen semi mekanis dan manual, berdasar tingginya nilai denyut jantung kerja, beban kerja operator mesin combine ini relatif ringan, diikuti pekerja panen semi mekanis dan yang paling berat pekerja panen manual. Beban kerja operator combine ini dipengaruhi oleh kebisingan mesin, suhu lingkungan serta getaran mesin (Mulyati dkk., 2020a).

\section{Kesakitan Akibat Kerja}

Kuesioner Standard Nordic Questionare yang lebih dikenal dengan Nordic Body Map digunakan untuk

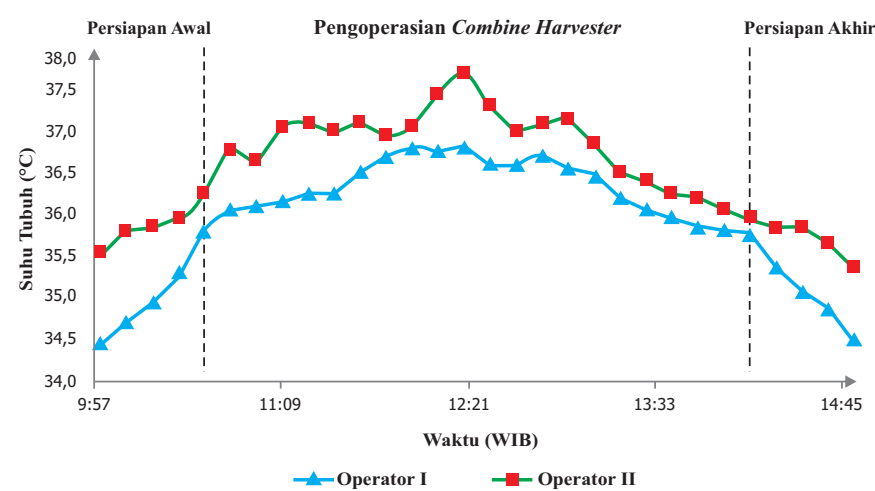

Gambar 2. Suhu Tubuh 
Tabel 9. Rerata konsumsi oksigen dan pengeluaran energi operator

\begin{tabular}{cccc}
\hline Operator & $\begin{array}{c}\text { Konsumsi } \\
\text { oksigen } \\
\text { (L/menit) }\end{array}$ & $\begin{array}{c}\text { Pengeluaran } \\
\text { energi } \\
\text { (kkal/menit) }\end{array}$ & Pekerjaan \\
\hline \multirow{2}{*}{ I } & 0,59 & 2,62 & persiapan awal \\
& 1,11 & 5,46 & Pengoperasian \\
Rata-rata & 0,58 & 2,66 & persiapan akhir \\
& 0,76 & 3,58 & \\
II & 0,54 & 2,79 & persiapan awal \\
& 0,19 & 5,66 & pengoperasian \\
Rata-rata & 0,56 & 2,75 & persiapan akhir \\
\hline \multirow{2}{*}{. } & 0,43 & 3,73 & \\
\hline
\end{tabular}

identifikasi bagian tubuh yang terasa sakit setelah bekerja. Rasa sakit yang dialami pekerja digolongkan sebagai Musculoskeletal Disorders (MSDs) yaitu sedera pada otot, tulang, sendi dan syaraf seperti rasa sakit, pegal, kesemutan, dan sebagainya. Operator diminta menilai rasa sakit yang dialami sebelum dan sesudah bekerja. Hasil penilaian terdapat pada Gambar 3. Operator mesin combine memerlukan area yang mencukupi untuk footstep dan area untuk melepas kelelahan kaki saat bekerja. Posisi duduk yang tetap, gerakan yang berulang, dan ketidakcukupan waktu istirahat menyebabkan MSDs (Anonim, 2018).

Melalui Standard Nordic Questionnaire (SNQ) dapat diketahui bagian-bagian otot yang mengalami keluhan dengan tingkat keluhan mulai dari rasa tidak nyaman (agak sakit) sampai sangat sakit (Corlett, 1992). Keluhan agak sakit yang dirasakan oleh operator pada bahu kanan dan tangan kanan disebabkan untuk menggerakkan tuas pengendali dibutuhkan tenaga yang cukup berat terutama pada saat belokan yang tajam. Operator harus menahan tuas pengendali belokan dalam waktu yang agak lama. Sedangkan keluhan sakit yang dirasakan operator pada bahu kiri disebabkan oleh letak tuas pengendali yang letaknya lebih rendah, sehingga operator memerlukan usaha lebih untuk menjangkau tuas tersebut.

Getaran pada tangan serta telapak tangan yang disebabkan oleh pengaruh osilasi mesin berakibat pada terhambatnya aliran darah di tangan yang menyebabkan deformasi pada tulang serta sambungan (joints) pada sistem kerangka-otot, serta sistem saraf (Nurmianto, 2008). Pada bagian tengkuk operator mengeluhkan rasa sakit, hal ini berhubungan dengan keluhan sangat sakit yang dirasakan pada bagian pinggang.

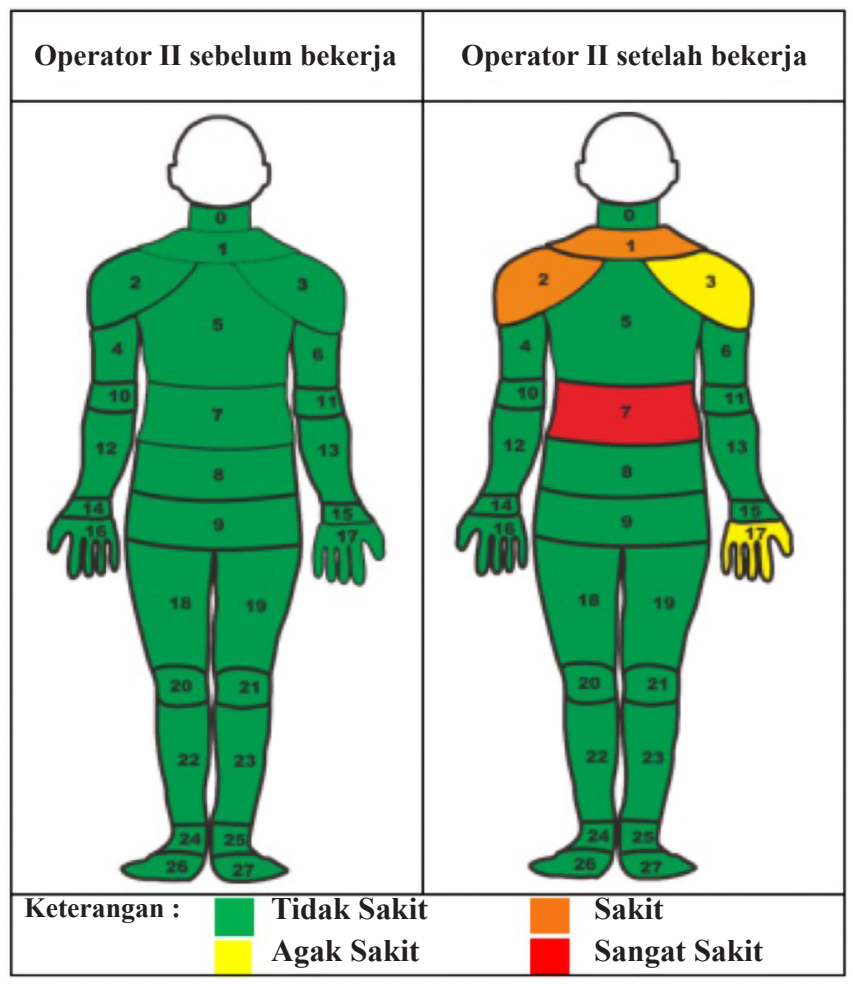

Gambar 3. Keluhan otot skeletal sebelum dan sesudah bekerja

Posisi kerja duduk terus-menerus pada waktu yang lama seperti yang terjadi pada pekerjaan operator mini rice combine harvester sangat tidak menguntungkan. Di samping pekerjaan akan terasa membosankan, beban kerja juga akan meningkat sehingga kelelahan cepat muncul. Operator mini rice combine harvester sering cepat mengalami kelelahan dan keluhan otot. Hal tersebut disebabkan antara lain karena mengendarai mesin bekerja dengan sikap statis, sarana kerja tidak sesuai dengan antropometri pemakainya, dan suhu lingkungan cukup panas. Menurut Astrand dan Rodahl (1986), kerja statis menyebabkan sensasi ketidaknyamanan, kelelahan dan kenyerian pada anggota tubuh tertentu.

Terjadinya keluhan pada pinggang disebabkan oleh tidak adanya posisi sandaran kursi yang antropometris pada mini combine sehingga tulang belakang dalam posisi tidak alamiah. Sikap paksa ini apabila terjadi dalam waktu lama, dapat menimbulkan rasa nyeri otot. Rasa nyeri ini akan bertambah karena duduk statis akan mengurangi kelancaran peredaran darah ke seluruh tubuh sehingga suplai darah ke otot juga menurun dan dapat menimbulkan kekejangan otot lokal. Sandaran pinggang ini penting untuk menahan beban punggung ke arah belakang sehingga dapat mengurangi keluhan di bagian punggung dan pinggang. Kriteria sandaran pinggang bagian atas dari sandaran pinggang tidak 
melebihi tepi bawah ujung tulang belikat dan bagian bawahnya setinggi garis pinggul (Nurmianto, 2008). Untuk kursi dengan waktu tempuh yang panjang, sandaran kursi yang dianjurkan dalam posisi normal membentuk sudut $105^{\circ}$, dan dapat disesuaikan atau diatur hingga sudut $135^{\circ}$ terhadap horizontal. Keluhankeluhan ini sebenarnya dapat diminimalkan dengan cara pengaturan sandaran dan bantalan kursi sehingga tulang belakang dalam posisi alamiah.

Terjadinya keluhan pada bagian tengkuk juga disebabkan karena posisi tempat duduk operator untuk mengendalikan jalannya mini rice combine berada di bagian belakang. Mengingat posisi tempat duduk operator mini rice combine yang terletak di ujung belakang, operator kesulitan untuk melihat bagian depan karena tertutup oleh badan mesin. Untuk mengontrol jalannya mesin pada arah yang tepat maka operator harus memiringkan kepalanya agar dapat melihat jalur atau jalan yang ingin dilalui. Gerakan leher yang memposisikan kepala agar dapat melihat jalur depan rice combine menyebabkan timbulnya rasa nyeri atau sakit pada bagian tengkuk.

Terjadinya keluhan pada bahu disebabkan tidak adanya sandaran bahu pada tempat duduk operator sehingga otot-otot pada bagian bahu tertarik. Selain itu posisi stang kemudi pada mini rice combine yang terlalu rendah menyebabkan bagian bahu untuk condong kedepan dan menimbulkan tekanan pada jaringan otot di bagian bahu dan tangan, bahkan dapat menyebabkan aliran darah diperlambat yang pada akhirnya menimbulkan rasa sakit. Duduk dalam waktu lama tanpa sandaran meningkatkan peluang terjadinya kesakitan pada bahu dan leher (Chandrasekaran dkk, 2003). Menurut Mulyati dkk (2020b) operator mesin combine seringkali mengoperasikan mesin sambil berdiri. Akan tetapi tipe mesin combine dalam penelitian ini tidak ada fasilitas untuk mengoperasikan mesin sambil berdiri, fasilitas hanya untuk duduk saja.

Masalah utama pada mesin combine harvester adalah tempat duduk yang kurang ergonomis, tidak sesuainya penempatan meja control karena menyebabkan tangan operator bekerja pada area kerja maksimal, sempitnya area untuk pergerakan kaki saat mengemudi dan tidak adanya footstep untuk operator berdiri dikala lelah duduk (Mulyati dkk., 2020b).

\section{KESIMPULAN}

Ditinjau dari sisi ergonomika, mesin mini rice combine harvester yang diuji mempunyai karakteristik mekanis yang kurang baik dari besarnya getaran dan kebisingan mesin yang mengakibatkan operator hanya boleh mengoperasikan tidak lebih dari 1 jam satu hari. Namun demikian mesin tidak menyebabkan polusi debu, dan dari sisi karakteristik fisiologi kerja operator yang meliputi beban kerja dan MSDs pada operator tidak menunjukkan risiko yang membahayakan.

\section{KONFILIK KEPENTINGAN}

Tidak ada konflik kepentingan antara penulis dengan pihak lain.

\section{DAFTAR PUSTAKA}

Abdulkarim, K. O., Abdulrahman, K. O., Ahmed, I. I., Abdulkareem, S., Adebisi J. A., \& Harmanto. (2017). Design of mini combined harvester. Journal of Production Engineering 20(1), 55-62. http://doi: 10.24867/JPE2017-01-055.

Almosawi, A. A., Alkhaafaji, A. J., \& Alqazzaz, K. K. (2016). Vibration transmission by combine harvester to the driver at different operative conditions during paddy harvest. International Journal of Science and Nature, 7(1), 127-133. https://www.researchgate.net/publication/298559244.

Anonim (2005). Clean Room Class Limits According ISO Standard 14644. International Organization for Standardization. Geneva.

Anonim (2013). Statistik Ketenagakerjaan Sektor Pertanian Tahun 2013. Pusat Data dan Sistem Informasi Pertanian, Kementrian Pertanian, Jakarta.

Anonim (2015). SNI 8185: 2015. Mesin Panen Padi Kombinasi (Paddy Combine Haervester) Syarat Mutu Dan Metode Uji. Badan Standarisasi Nasional.

Anonim (2018). Work-related Musculosceletal Disorders (WMSDs), Canadian Centre for Occupational Health and Savety 1978-2018. http://www.ccohs.ca/oshanswers/ diseases/rmirsi.html

Astrand, P. O. \& Rodahl, K. (1986). Textbook of Work Physiology. $2^{\text {nd }}$ Edition. WB Saunders Co. Philadelphia.

BPS (2013). Luas Kepemilikan Lahan Pertanian, Sensus Pertanian 2013. BPS.

Bulduk, E. O., Bulduk, S., Süren, T., \& and Ovalı, F. (2014). Assessing exposure to risk factors for work-related musculoskeletal disorders using quick exposure check (GEC) in taxi drivers. International Journal of Industrial Ergonomics, 44, 817-820. http://doi: 10.1016/j. ergon.2014.10.002.

Corlett, E. N. (1992). Static Muscle Loading and the Evaluation of Posture. Tailor \& Francis. London.

Charles, L. E., Ma, C. C., Burchfiel, C. M., \& Dong, R. G. (2017). Vibration and ergonomic exposure associated 
with musculoskeletal disorders of the shoulder and neck. Safety and Health at Works (2017), 1-8, http:// doi.org/10.1016/j.shaw.2017.10.003.

Depkes RI. (1997). Peraturan Menteri Kesehatan RI No 416/Menkes/Per/IX/1997. Departemen Kesehatan RI. Jakarta.

Depkes RI. (2016), Peraturan Menteri Kesehatan Republik Indonesia No 70 Tahun 2016. Departemen Kesehatan RI. Jakarta.

Ghaderi, E., Maleki, A., \& Dianat, I. (2014). Design of combine harvester seat based on anthropometric data of Iranian operators. International Journal of Industrial Ergonomics, 44, 810-816. Doi: 10.1016/j.ergon.2014.10.003

Guastello (2014). Human factors engineering and ergonomics. CRC Press, New York.

Herodian, S. \& Saulia, L. (1998). Ergonomika. Institut Pertanian Bogor. Bogor.

Iridiastadi \& Yasierli (2014). Ergonomi Suatu Pengantar. PT Remaja Posdakarya, Bandung.

Kroemer, K., Kroemer, H., \& Kroemer-Elbert, K. (2004). Ergonomics: How to Design for Ease and Efficiency. Prentice Hall, New Jersey.
Mehta, M., Gandhi, S., \& Dilbaghi, M. (2012). intervention of drudgery educing technologies in agriculture and impact evaluation. Work, 41, 5003-5008. Doi: 10.3233/WOR2012-0793-5003

Mulyati, G. T., Maksum, M., Purwantana, B. \& Ainuri, M. (2020a). The workload of rice harvester in Java Indonesia. Earth Environ. Sci., 425. Doi: 10.1088/17551315/425/1/012035.

Mulyati, G. T., Maksum, M., Purwantana, B. \& Ainuri, M. (2020b). The conformities design of indonesian made mini rice combine harvester and anthropometry Javanese farmer. agriTECH 40(2): 133-140. doi.org/10.22146/ agritech.49044.

Nurmianto, E. (2008). Ergonomi (Konsep dasar dan Aplikasinya). Guna Widya. Surabaya.

Sulaiman, A. A. (2018), Indonesia Menuju Lumbung Pangan Dunia 2025. Kuliah tamu Menteri Pertanian Republik Indonesia di Fakutas Pertanian Universitas Gadjah Mada, 12 Maret 2018.

Sumer, S. K., Ege, F., Say, S. M., \& Sabanci, A. (2006). noise exposed of the operators of combine harvesters with and without a cab. Applied Ergonomics, 37(6), 749-56, Doi: 10.1016/j.apergo.2005.11.006. 